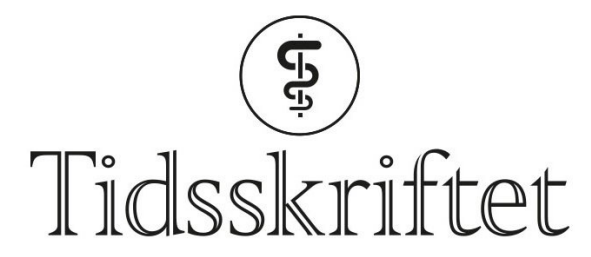

DEN NORSKE LEGEFORENING

\title{
Lovende vaksine mot MERS-infeksjon
}

FRA ANDRE TIDSSKRIFTER

\section{KRISTOFFER BRODWALL}

E-post: kristoffer.brodwall@gmail.com

Barne- og ungdomsklinikken

Haukeland universitetssjukehus

Sykdommen midtøstluftveissyndrom - ofte forkortet MERS - har høy dødelighet. En vaksine er under utprøving.

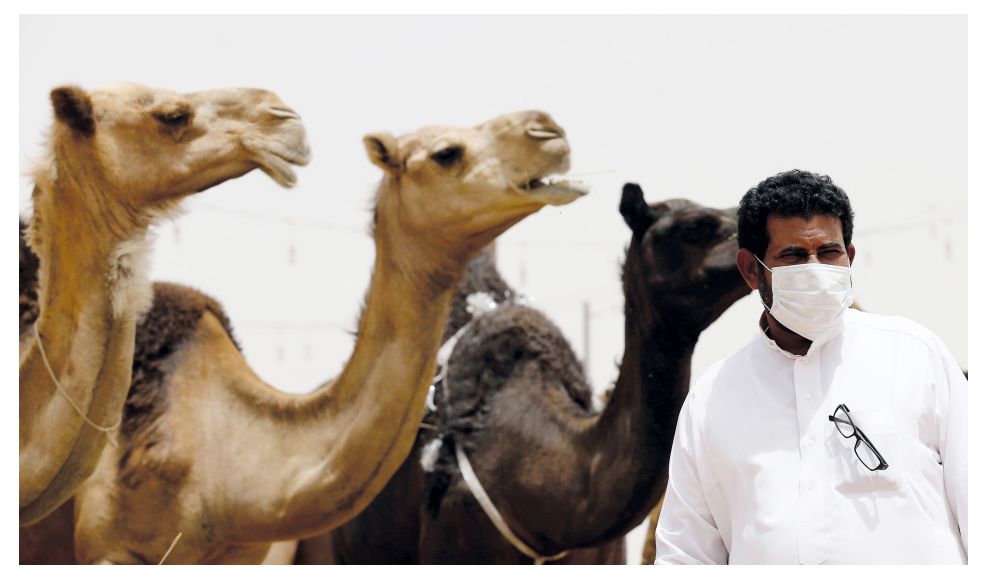

Overføringsveien fra dyr til mennesker er ikke helt forstått, men dromedar og kamel er den viktigste reservoarverten for midtøstluftveissyndrom. I 2014 ba saudiarabiske myndigheter personer som håndterer kameler om å på seg masker og hansker for å forhindre spredning av sykdommen. Foto: Reuters / NTB scanpix

Midtøstluftveissyndrom, på engelsk Middle East Respiratory syndrome (MERS), ble beskrevet første gang i 2012 og har siden blitt diagnostisert basert på laboratoriefunn hos flere enn 2 400 personer. Sykdommen skyldes et coronavirus og har høy dødelighet; rundt hver tredje pasient dør. De fleste tilfellene er registrert i Saudi-Arabia, men sykdommen er påvist i 27 land, bl.a. Sør-Korea, der et utbrudd med nesten 200 smittede ble sporet tilbake til én person. Dette viser at sykdommen kan spre seg som en epidemi.

Det finnes ingen vaksine mot denne infeksjonen, men det er nå gjennomført en fase 1-studie av en mulig vaksine, kalt GLS-530o (1). Studien omfattet 75 friske voksne personer som fikk vaksinen i tre ulike doser, gitt som intramuskulær injeksjon, ved studiestart og fire og tolv uker senere. Serokonvertering, målt ved ELISA-teknikk, ble påvist hos $86 \%$ etter to injeksjoner og hos $94 \%$ etter tre injeksjoner. Nøytraliserende antistoffer ble påvist hos halvparten og T-cellerespons hos $71 \%$ og $76 \%$ etter henholdsvis to og tre injeksjoner. Det var ingen forskjell mellom gruppene som hadde fått ulike vaksinedoser. Vaksineresponsen var fortsatt til stede etter 60 uker. 
Det var ingen alvorlige bivirkninger. Nesten alle deltakerne fikk en lokal reaksjon ved injeksjonsstedet og en mild bivirkning som hodepine eller slapphet. Seks personer fikk en mild infeksjon som ble antatt å ha sammenheng med injeksjonen.

Forfatterne konkluderer med at GLS-5300-vaksinen blir godt tolerert og at den gir en immunrespons som rettferdiggjør videre utprøving.

\section{LITTERATUR:}

1. Modjarrad K, Roberts CC, Mills KT et al. Safety and immunogenicity of an anti-Middle East respiratory syndrome coronavirus DNA vaccine: a phase 1, open-label, single-arm, dose-escalation trial. Lancet Infect Dis 2019; 19: 1013-22. [PubMed][CrossRef]

Publisert: 28. oktober 2019. Tidsskr Nor Legeforen. DOI: 10.4045/tidsskr.19.0633

(C) Tidsskrift for Den norske legeforening 2020. Lastet ned fra tidsskriftet.no 